\title{
FERTILIZING ABILITY OF THE TEXEL RAM-SIRES THAWED SPERM UNDER DIFFERENT MODES OF THEIR USE
}

\author{
Laboratory of Biotechnology of Reproduction, Institute of Animal Biology, National Academy \\ of Agricultural Sciences of Ukraine, Lviv, Ukraine \\ ${ }^{1}$ Department of Livestock, National Academy of Agricultural Sciences of Ukraine, Lviv, Ukraine
}

\begin{abstract}
The article presents the results of experimental studies on the effect of the quality of ram-sires' thawed sperm during the breeding and non-breeding periods under different modes of using the breeders. It is established that the acrosome preservation under the mode of using the ram-sires to receive 4 ejaculates per week compared to 6 and 8 ejaculates during the nonbreeding period was higher by 3.5 and $6.0 \%$, respectively, and by 2.5 and 5.0 percent during the breeding period. Kinetic parameters of sperm motion during both periods of seasonal activity were also higher under the mode of receiving 4 ejaculates per week by 2.6-14.0 percent on average. The fertilizing ability of thawed sperm from the first insemination of ewes under the mode of receiving 4 ejaculates per week compared to the above mentioned modes was higher by 3.2 and $7.2 \%$ during the non-breeding period, and by 7.3 and $10.6 \%$ during the breeding period; while fertility at lamb birth - by 1.7 and $3.8 \%$, and by 1.0 and 8.1 percent, respectively.
\end{abstract}

Key words: ram-sires, ewes, lambs, modes of use, periods of seasonal activity, thawed sperm, acrosome, kinetic parameters, fertility.

\section{INTRODUCTION}

In sheep selective breeding, ram-sires play a special role in improving flocks thanks to both the quantity and quality of the resulting offspring (Pomitun 2004; Bolotov et al. 2008; Ibatullin et al. 2016). The widespread introduction of modern biotechnological methods of reproduction, particularly laparoscopic artificial insemination of ewes with deep-frozen semen, requires intensive use of valuable, elite rams (Malmakov et al. 2001; Ajbazov et al. 2004; Auzbaev 2010; Tibary et al. 2018). Therefore, studying the impact of seasonal activity and the mode of using ram-sires on the qualitative indicators of thawed sperm and its fertilizing ability expresses a scientific and applied interest.

When assessing the qualitative indicators of sperm, special attention is paid to two extremely important integral indicators: preservation of sperm acrosome after cryopreservation and its kinetic movement; which according to many researchers (Sokolovskaya et al. 1981; Minich et al. 1990; Turchanov 2007; Siratskyi et al. 2009; Rajashri et al. 2017) are indicators of biological sperm quality and have a positive correlation with their fertilizing ability.

Corresponding author: Stakh Vovk, Department of Livestock, Institute of Agriculture in the Carpathian Region National Academy of Agricultural Sciences of Ukraine, Lviv region, Ukraine, Pustomyty district, Obroshyno village, 81115, e-mail: vovkstah@gmail.com 
In previous our studies, the influence of the season sexual activity on qualitative indices of sperm of different breeds of rams was investigated (Sharan et al. 2018). Breeding of texel sheep, using modern biotechnological methods of reproduction, is becoming popular in Ukraine during the past few years, therefore, it is necessary to obtain high-quality semen of rams throughout the year. That's why, the purpose of our research was to study the qualitative indices of the sperm of texel ram-sires in different periods of sexual activity.

\section{MATERIAL AND METHODS}

The experimental part of the work was performed in the Laboratory of biotechnology of reproduction, Institute of Animal Biology of the National Academy of Agricultural Sciences, the gene pool laboratory of Lviv Research and Production Center (ZNHC) "Zahidplremresursy", peasant farm organization "Kogut B. M. ", Gorodotsky district, Lviv region.

Six texel ram-sires aged 3-4 years old and 120 ewes were used in the experiment. The conditions for keeping and feeding the experimental rams and ewes during the experiment were the same. The sheep and ewes were fed on a diet formulated to meet the recommended feeding standards, taking into account the optimal ratio of nutritional content (Ibatullin et al. 2015).

Experimental ram-sires were kept indoors at night, while they were in the loafing areas with canopies in the daytime. In summer, the sheep grazed on pasture, with strictly following the rational daily routine.

In order to establish the optimal mode of using ram-sires in different periods of seasonal activity (breeding and non-breeding), their sperm was obtained under such modes: 4 ejaculates per week (2 douplet selection, 2 times a week); 6 -ejaculate per week ( 2 douplet selection, 3 times a week); 8 ejaculate per week (2 douplet selection, 4 times a week).

Sperm was collected by artificial vagina. Freshly obtained ejaculates were evaluated by volume $(\mathrm{ml})$, sperm concentration (billion $/ \mathrm{ml}$ ), total amount of sperm in the ejaculate (billion), mass motility (points), the amount of sperm with a straight-forward movement (\%) and according to conventional methods. Ram sperm with motility of at least 8 points and concentration of not less than $2.5 \mathrm{bln} / \mathrm{ml}$ was diluted $1: 3$ with lactose-yolk-tris-citrate-glycerine diluent. After that, using the Minitube equipment, $0.25 \mathrm{ml}$ straws were filled with the diluted sperm, put into the refrigerator at the temperature of $4^{\circ} \mathrm{C}$, equilibrated for 3 hours and then held above nitrogen vapour for 7 minutes $\left(-120^{\circ} \mathrm{C}\right)$ in a special vessel. Then, the straws were packaged in tapes and dipped in liquid nitrogen for storage.

The frozen semen was thawed in a water bath $\left(38^{\circ} \mathrm{C}\right)$ for $18-20$ seconds, carefully removed the moisture, unpacked the peyets with scissors and evaluated. In thawed sperm, the quality of spermatozoa: motility after adaptation and cryopreservation and kinetic sperm indicators such as: curvilinear velocity (VCL), average path velocity (VAP), straight line velocity $(\mathrm{VSL})$. linearity degree $(\mathrm{LIN}=\mathrm{VSL} / \mathrm{VCL})$, sperm straightness $(\mathrm{STR}=\mathrm{VSL} / \mathrm{VAP})$, wobble coefficient (WOB = VAP / VCL), was determined by using the CASA computer system (Computer Assisted System Analysis) - Sperm-Vision (Verstegen et al. 2002). The acrosome damage was determined using Sokolovskaya method (Sokolovskaya et al. 1981). 
For the comparative study of the fertilizing ability of ram-sires' sperm in different periods of seasonal activity under different modes of use, the frozen-thawed sperm selected in May-June-July (non-breeding period) and in August-September-October (breeding period) was used for the insemination of ewes. For this, a group of texel sheep was picked according to the analogue principle, 120 animals by taking age, live weight, nutritional and physiological state into account. After that the group was divided into 6 subgroups. The first three were inseminated with the sperm frozen in the non-breeding period under different modes of using ram-sires, while the second three - in the breeding period under different modes, too. For artificial insemination, with signs of hunting on visual supervision and by using ram-probes, clinically healthy sheep of average fatness were selected and inseminated by a laparoscopic method.

While in our previous studies, when evaluating the ram-sires' sexual activity in the breeding and non-breeding periods, higher rates were found under the mode of sperm selection 4 ejaculates per week, in this experiment, the main quantitative and qualitative indicators of sperm under the same use mode were compared with those obtained under the mode 6 and 8 ejaculates per week.

All calculations were performed using Statistica software (StatSoft 2009).

\section{RESULTS AND DISCUSSION}

Numerous studies show that seasonal climatic factors and high sexual capacity lead to a decrease in sexual activity and quantitative and qualitative indicators of ram-sires' sperm productivity (Cassao et al. 2010; Azawi et al. 2012; Martia et al. 2012). As well as, cryopreservation, as a technique, causes the reduceing of the quality of thawed semen, such as, rates of motility, acrosomal integrity, and lead to low fertility (Kasai et al. 2002; Awad 2011).

The analysis of the acrosome preservation showed that in the non-breeding period under the mode of obtaining 4 ejaculates per week, the percentage of spermatozoa with the damaged acrosome was $32.00 \%$, out of which $11.56 \%$ was with a swollen acrosome, $9.00 \%$ with a separated acrosome, $7.00 \%$ - with a lost acrosome, and $4.44 \%$ - total loss of the head. Under the mode of obtaining 6 ejaculates per week, these indicators were higher: damaged acrosome - by $3.5 \%$, swollen acrosome - by $0.48 \%$, separated acrosome - by $0.71 \%$, lost acrosome - by $1.00 \%$ and total loss of the head - by $1.31 \%$, and under the mode of obtaining 8 ejaculates per week: damaged acrosome - by $6.0 \%$ ( $p<0.05$ ), swollen acrosome - by $1.94 \%$, separated acrosome - by $1.87 \%$, lost acrosome - by $0.95 \%$ and total loss of the head - by $1.24 \%$ compared to the mode of obtaining 4 ejaculates per week (Table 1).

In the breeding period, under the mode of obtaining 4 ejaculates per week, the amount of sperm with a damaged acrosome accounted for $25.50 \%$, which is by 2.5 and 5.0 percent $(p<0.05)$ less compared to that of receiving 6 and 8 ejaculates, respectively.

In order to obtain detailed indicators of sperms movement, we studied their kinetic parameters by the CASA computer system. The sperm curvilinear velocity (VCL) in the nonbreeding period under the mode of using ram-sires with receiving 4 ejaculates per week made up $152.65 \mu \mathrm{m} / \mathrm{s}$, and was higher by 5.5 and 12.3 percent $(p<0.001)$ than that under the mode of receiving 6 and 8 ejaculates (Table 2). 
Table 1. Preservation of sperm acrosome after cryopreservation, depending on the mode of using texel ram-sires in non-breeding and breeding periods, $M \pm m, n=6$

\begin{tabular}{|c|c|c|c|c|c|c|}
\hline \multirow{4}{*}{ Indicator } & \multicolumn{6}{|c|}{ Period of seasonal activity } \\
\hline & \multicolumn{3}{|c|}{ non-breeding } & \multicolumn{3}{|c|}{ breeding } \\
\hline & \multicolumn{6}{|c|}{ mode of using the ram-sires per week, ejaculates } \\
\hline & $4 \times 2$ & $3 \times 2$ & $2 \times 2$ & $4 \times 2$ & $3 \times 2$ & $2 \times 2$ \\
\hline $\begin{array}{l}\text { Investigated } \\
\text { semen straws }\end{array}$ & 24 & 24 & 24 & 24 & 24 & 24 \\
\hline $\begin{array}{l}\text { Motility of frozen- } \\
\text {-thawed semen } \\
\text { [points] }\end{array}$ & $3.63 \pm 0.18$ & $3.79 \pm 0.15$ & $3.92 \pm 0.13$ & $4.08 \pm 0.12$ & $4.25 \pm 0.13$ & $4.38 \pm 0.13$ \\
\hline $\begin{array}{l}\text { Sperm without } \\
\text { damaged } \\
\text { acrosome [\%] }\end{array}$ & $62.00 \pm 1.64^{*}$ & $64.50 \pm 1.79$ & $68.00 \pm 2.04$ & $69.50 \pm 1.85^{*}$ & $72.00 \pm 1.83$ & $74.50 \pm 1.06$ \\
\hline $\begin{array}{l}\text { Sperm with } \\
\text { damaged } \\
\text { acrosome [\%] } \\
\text { out of which: }\end{array}$ & $38.00 \pm 1.53^{*}$ & $35.50 \pm 1.49$ & $32.00 \pm 2.00$ & $30.50 \pm 1.73^{*}$ & $28.00 \pm 1.71$ & $25.50 \pm 1.00$ \\
\hline $\begin{array}{l}\text { swollen } \\
\text { acrosome }\end{array}$ & $13.50 \pm 0.62^{*}$ & $12.04 \pm 0.58$ & $11.56 \pm 0.82$ & $10.00 \pm 0.56^{*}$ & $9.42 \pm 0.49$ & $8.52 \pm 0.38$ \\
\hline $\begin{array}{l}\text { separated } \\
\text { acrosome }\end{array}$ & $10.87 \pm 0.49^{*}$ & $9.71 \pm 0.51$ & $9.00 \pm 0.71$ & $8.46 \pm 0.69^{*}$ & $7.40 \pm 0.60$ & $6.96 \pm 0.24$ \\
\hline lost acrosome & $7.95 \pm 0.37$ & $8.00 \pm 0.53$ & $7.00 \pm 0.56$ & $7.16 \pm 0.59$ & $6.28 \pm 0.66$ & $6.00 \pm 0.31$ \\
\hline $\begin{array}{l}\text { total loss of the } \\
\text { head }\end{array}$ & $5.68 \pm 0.31$ & $5.75 \pm 0.68$ & $4.44 \pm 0.30$ & $4.88 \pm 0.39$ & $4.90 \pm 0.46$ & $4.02 \pm 0.43$ \\
\hline
\end{tabular}

Table 2. Kinetic parameters of the thawed sperm depending on the mode of using texel ram-sires in non-breeding and breeding periods, $M \pm m, n=6$

\begin{tabular}{|c|c|c|c|c|c|c|}
\hline \multirow{4}{*}{ Indicator } & \multicolumn{6}{|c|}{ Period of seasonal activity } \\
\hline & \multicolumn{3}{|c|}{ non-breeding } & \multicolumn{3}{|c|}{ breeding } \\
\hline & \multicolumn{6}{|c|}{ mode of using the ram-sires per week, ejaculates } \\
\hline & $4 \times 2$ & $3 \times 2$ & $2 \times 2$ & $4 \times 2$ & $3 \times 2$ & $2 \times 2$ \\
\hline $\begin{array}{l}\text { Investigated } \\
\text { semen straws }\end{array}$ & 192 & 144 & 96 & 192 & 144 & 96 \\
\hline $\begin{array}{l}\text { Motility } \\
\text { of frozen- } \\
\text {-thawed semen }\end{array}$ & $43.92 \pm 0.60^{* *}$ & $47.42 \pm 0.46$ & $48.17 \pm 0.90$ & $51.45 \pm 0.56^{* * *}$ & $53.77 \pm 0.51^{\star *}$ & $57.40 \pm 0.82$ \\
\hline $\begin{array}{l}\text { Sperm with } \\
\text { straight-forward } \\
\text { movement [\%] }\end{array}$ & $34.52 \pm 0.64^{*}$ & $36.32 \pm 0.50$ & $37.50 \pm 0.87$ & $39.81 \pm 0.66^{* * *}$ & $41.87 \pm 0.56^{\star *}$ & $44.50 \pm 0.61$ \\
\hline $\operatorname{VCL}[\mu \mathrm{m} / \mathrm{s}]$ & $133.95 \pm 0.88^{* * *}$ & $144.23 \pm 1.32^{* * *}$ & $152.65 \pm 1.43$ & $154.62 \pm 0.70^{\star \star *}$ & $165.84 \pm 0.58$ & $170.30 \pm 0.93$ \\
\hline $\operatorname{VAP}[\mu \mathrm{m} / \mathrm{s}]$ & $62.91 \pm 0.67^{* * *}$ & $68.72 \pm 0.62^{* \star \star}$ & $73.12 \pm 0.76$ & $74.79 \pm 0.48^{* \star *}$ & $80.84 \pm 0.60^{* * *}$ & $85.29 \pm 0.32$ \\
\hline $\mathrm{VSL}[\mu \mathrm{m} / \mathrm{s}]$ & $52.85 \pm 0.63^{* * *}$ & $56.36 \pm 0.52^{* * *}$ & $61.38 \pm 0.70$ & $63.50 \pm 0.52^{* * *}$ & $68.50 \pm 0.13^{* * *}$ & $71.80 \pm 0.50$ \\
\hline LIN [\%] & $39.45 \pm 0.47$ & $39.08 \pm 0.16$ & $40.21 \pm 0.55$ & $41.07 \pm 0.41$ & $41.31 \pm 0.17$ & $42.16 \pm 0.33$ \\
\hline STR [\%] & $84.00 \pm 0.72$ & $82.01 \pm 0.33$ & $83.94 \pm 1.07$ & $84.90 \pm 0.74$ & $84.74 \pm 0.67$ & $84.18 \pm 0.78$ \\
\hline WOB [\%] & $46.97 \pm 0.49$ & $47.65 \pm 0.12$ & $47.90 \pm 0.62$ & $48.37 \pm 0.44$ & $48.74 \pm 0.40$ & $50.08 \pm 0.34$ \\
\hline
\end{tabular}

Explanations see Table 1.

The velocity of the sperm head along the average path of motion (VAP) and the velocity of rectilinear movement of the sperm head along the straight line between the initial and final points of the path (VSL) under the mode of obtaining 4 ejaculates per week were higher by 6.0 and $14.0 \%(p<0.001)$, and 8.2 and 13.9 percent $(p<0.001)$ respectively. However, such kinetic parameters as the linearity degree (LIN), straightness of the sperm motion (STR) and wobble coefficient (WOB) were practically at the same level, the difference between them was only 0.3 to 1.9 percent. 
In the breeding period, under the mode of obtaining 4 ejaculates per week, the sperm curvilinear velocity was higher in comparison with that under the mode of obtaining 6 and 8 ejaculates by 2.6 and $9.2 \%$. The velocity of the sperm head along the average path of motion and the velocity of rectilinear movement of the sperm head along the straight line between the initial and final points of the path were higher by 5.2 and $12.3 \%$, and 4.6 and 11.6 percent $(p<0.001)$, respectively. The parameters of sperm motion differed slightly from 0.6 to $1.7 \%$ under the studied modes of using the ram-sires, by linearity, straightness and wobble.

The study of sperm kinetic parameters revealed that the sperm curvilinear velocity, the velocity of the sperm head along the average path of motion and the velocity of rectilinear movement of the sperm head along the straight line between the initial and final points of the path were higher in the breeding period compared with non-breeding period by 10.4, 13.0, $13.4 \%$ and $14.3,15.0,15.9 \%$ and $14.5,17.7,16.8$ percent $(p<0.001)$ respectively. The higher sperm velocity parameters during the breeding period contributed to increased linearity by $1.9,2.2,1.6 \%$, straightness degree by $0.2,2.7,0.9 \%$, wobble coefficient by 2.2 , $1.1,1.4$ percent.

Laboratory studies of ram-sires' sperm production are confirmed by scientific experiment on fertilizing capacity of the thawed sperm obtained in non-breeding and breeding periods under various modes of using ram-sires (Table 3).

Table 3. Fertilizing capacity of ram-sires' thawed sperm in the breeding and non-breeding periods depending on the mode of use, $n=6$

\begin{tabular}{|c|c|c|c|c|c|c|}
\hline \multirow{4}{*}{$\begin{array}{c}\text { Indicator } \\
{[\%]}\end{array}$} & \multicolumn{6}{|c|}{ Period of seasonal activity } \\
\hline & \multicolumn{3}{|c|}{ non-breeding } & \multirow{2}{*}{\multicolumn{3}{|c|}{ breeding }} \\
\hline & \multicolumn{4}{|c|}{ mode of using the ram-sires per week, ejaculates } & & \\
\hline & $4 \times 2$ & $3 \times 2$ & $2 \times 2$ & $4 \times 2$ & $3 \times 2$ & $2 \times 2$ \\
\hline $\begin{array}{l}\text { No. of inseminated } \\
\text { sheep }\end{array}$ & 18 & 20 & 22 & 18 & 20 & 22 \\
\hline $\begin{array}{l}\text { Fertilization rate of } \\
\text { the ewes after first } \\
\text { insemination, } \\
\text { heads }\end{array}$ & $11-61.1$ & $13-65.0$ & $15-68.2$ & $12-66.7$ & 14-70.0 & $17-77.3$ \\
\hline $\begin{array}{l}\text { Fertilization rate of } \\
\text { the ewes after all } \\
\text { inseminations }\end{array}$ & 88.9 & 90.0 & 90.9 & 94.4 & 95.0 & 95.5 \\
\hline $\begin{array}{l}\text { Number of ewes } \\
\text { that have lambed, } \\
\text { heads }\end{array}$ & 16 & 18 & 20 & 17 & 19 & 21 \\
\hline $\begin{array}{l}\text { No. of lambs } \\
\text { lambed }\end{array}$ & 29 & 33 & 37 & 31 & 36 & 40 \\
\hline Fertility index & 181.2 & 183.3 & 185.0 & 182.4 & 189.5 & 190.5 \\
\hline $\begin{array}{l}\text { Number of lambs } \\
\text { weaned, heads }\end{array}$ & 26 & 30 & 34 & 29 & 33 & 37 \\
\hline $\begin{array}{l}\text { Fertility index after } \\
\text { weaning }\end{array}$ & 144.4 & 150.0 & 154.5 & 161.1 & 165.0 & 168.2 \\
\hline Lamb survival & 89.7 & 90.9 & 91.9 & 90.6 & 91.7 & 92.5 \\
\hline
\end{tabular}

In the non-breeding period, the fertility of the thawed sperm from the first insemination under the mode of receiving 4 ejaculates per week, made up $68.2 \%$ and was by 3.2 and 7.1 percent higher than the fertility of the thawed sperm obtained under the mode of 6 and 8 ejaculates. While the fertility from all inseminations was almost the same at $90.9-88.9 \%$, the fertility at the birth of lambs under the mode of 4 ejaculates per week was higher by 1.7 and 
$3.8 \%$ compared to that received under the mode of 6 and 8 ejaculates. The fertility at separation was also higher under the mode of obtaining 4 ejaculates by 4.5 and 10.1 percent respectively.

In the breeding period, the fertility of the thawed sperm from the first insemination under the mode of receiving 4 ejaculates per week, made up $77.3 \%$, which is by 7.3 and $10.6 \%$ higher than the sperm obtained under the mode of 6 and 8 ejaculates. The fertilizing ability of the sperm obtained under the studied modes of using ram-sires from all inseminations was practically the same ranging from 94.4 to $95.5 \%$. However, the fertility at lamb birth was somewhat different and amounted to $190.5 \%$ under the mode of 4 ejaculates per week and was higher by 1.0 and $8.1 \%$ respectively than that under other modes. The fertility at separation slightly differed under the studied modes and accounted for 168.2, 165.0 and 161.1 percent respectively.

Thus, the studied reproduction parameters in the non-breeding and breeding periods under the mode of obtaining 4 ejaculates per week were higher by $1.0-7.3 \%$ compared to those under the mode of receiving 6 ejaculates and by $3.8-10.6 \%$ under the mode of 8 ejaculates.

The fertilizing ability of the thawed sperm in the breeding period compared with the nonbreeding one had slightly higher rates. Thus, the fertility of the ewes from the first insemination was higher under all studied modes of using ram-sires by $9.1,5.0$ and $5.6 \%$ respectively. The fertility of ewes from all inseminations and the fertility at birth were also higher in the breeding season by $4.6,5.0,5.5 \%$ and $5.5,6.2,1.2$ percent respectively.

\section{CONCLUSIONS}

The experiment results show that the investigated qualitative parameters of the thawed sperm, its fertilizing ability in both periods of seasonal activity, were higher under the mode of using ram-sires with obtaining 4 ejaculates per week. We recommend using texel ram-sires with a mode of use 2 times a week for 2 ejaculations.

\section{REFERENCES}

Ajbazov M.M., Aboneev V.V., Sely’onova M.Y. 2004. Biotehnologija vosproizvodstva ovets i koz. Stavropol, [b.w.], 324. [in Russian]

Auzbaev S.A. 2010. Hranenie spermyi baranov $v$ zhidkom azote [Storage of sperm of rams in liquid nitrogen]. Nauka y obrazovanye 2(19), 70-71. [in Russian]

Awad M.M. 2011. Effects of sub-optimal glycerol concentration and cholesterol-loaded cyclodextrin in a Tris-based diluent on cryopreserved ram sperm longevity and acrosomal integrity. Small Rum. Res. 100(2-3), 164-168.

Azawi O.I., Ismaeel M.A. 2012. Effects of seasons on some semen parameters and bacterial contamination of Awassi ram semen. Repr. Domestic Anim. 47(3), 403-406.

Bolotov Yu. I., Korinecz N.O. 2008. Rezultaty osimeninnia vivtsematok tavriiskoho typu askaniiskoi tonkorunnoi porody spermoiu, kriokonservovanoiu za riznymy tekhnolohiiamy [Results of insemination of Tauride-type Sheeps of Ascanian fine-grained breed with semen cryopreserved according to different technologies]. Nauk. Visnyk «Askaniya Nova» 1, 213-217. [in Ukrainian] 
Casao A., Cebrián I., Asumpção M.E., Pérez-Pé R., Abecia J.A., Forcada F., Muiño-Blanco T. 2010. Seasonal variations of melatonin in ram seminal plasma are correlated to those of testosterone and antioxidant enzymes. Repr. Biol. Endocrinol. 8(1), 59.

Ibatullin I.I., Melnyk Yu.F., Otchenashko V.V.,. Sychov M.Yu., Kryvenok M.Ya., Chyhryn A.I., Kondratiuk V.M., Ilchuk I.I., Umanets D.P., Yatsenko O.V., Balanchuk I.M. 2015. Praktykum z hodivli silskohospodarskykh tvaryn: navchalnyi posibnyk. Kyiv, [b.w.], 422. [in Ukrainian]

Ibatullin I.I., Pabat V.O., Tury'ns'ky’j V.M. 2016. Stan ta shlyaxy pidvyshhennya eksportnogo potencialu galuzi vivcharstva Ukrayiny [The state and ways of increasing the export potential of the sheep breeding industry in Ukraine]. Naukovyj Visnyk Nacionalnogo Universytetu Bioresursiv i Pryrodokorystuvannya Ukrayiny 236, 30-45. [in Ukrainian]

Kasai T., Ogawa K., Mizuno K., Nagai S., Uchida Y., Ohta S., Hoshi K. 2002. Relationship between sperm mitochondrial membrane potential, sperm motility, and fertility potential. Asian J. Androl. 4(2), 97-104.

Malmakov N.,Y'., Medeubekov K.U., Asylbekova K.K, Tomas D.L., Gotfredson R.G. 2001. Povyishenie effektivnosti iskusstvennogo osemeneniya ovets zamorozhennyim semenem [Increasing the efficiency of artificial insemination of sheep with frozen semen]. Ovtsyi. Kozyi. Sherstnoe Delo 3, 23-28. [in Russian]

Martí J.I., Aparicio I.M., Leal C.L.V., García-Herreros M. 2012. Seasonal dynamics of sperm morphometric subpopulations and its association with sperm quality parameters in ram ejaculates. Theriogenology 78(3), 528-541.

Minich L.A., Danilevich Zh. S., lonash G.I. 1990. Otsenka byikov - proizvoditeley po biologicheskoy polnotsennosti ih spermyi. Intensifikatsiya proizvodstva moloka i govyadinyi: sb. nauch. [b.w.], 46-49. [in Russian]

Pomitun I.A. 2004. Pokaznyky vidtvoriuvalnoi zdatnosti ta osoblyvosti selektsii na yikh pidvyshchennia u ovets porody prekos [Indicators of reproductive capacity and breeding specialties on their increase in premium sheep breeds]. Naukovo-texnichnyj byuleten Instytutut Tvarynnycztva UAAN 86, 87-93. [in Ukrainian]

Rajashri M., Reddy K.R., Kumari G.A., Kumari N.N., Kesharwani S. 2017. Correlation between Hypo-osmotic Swelling Test (Host) and other seminal characteristics. J. Exp. Biol. Agric. Sci. 5(2), 195-200.

Sharan M., Hrymak K., Yaremchuk I. 2018. Udoskonalennya metody'ky' pidgotovky' baranivplidny'kiv do vzyattya spermy "[Improvement of the method of preparation of ram-sires for the semen collection]. Sci. Mess. LNU Veter. Med. Biotechnol. 20(84), 115-120. [in Ukrainian]

Siratskyi Y.Z., Boiko. O.V., Kamenska I.S., Fedorovych Ye.I., Fedorovych V.V., Hurskyi I.M. 2009. Morfolohichni pokaznyky spermy ta aktyvnist aminotransferaz u plazmi spermy buhaiv novykh ukrainskykh molochnykh pored [Morphological parameters of sperm and activity of aminotransferases in sperm plasma of bulls of new Ukrainian breeds]. Rozveden. Henetyka Tvaryn, Mizhvidomchyi Tematychnyi Naukovyi Zbirnyk 43, 289-300. [in Ukrainian]

Sokolovskaya Y.Y., Ojvady`s R.N., Abylov A. 1981. O znachenii akrosomyi v otsenke semeni samtsov [The importance of the acrosome in the estimation of the semen]. Zhyvotnovodstvo 9, 46-47. [in Russian]

StatSoft, Inc/ STATISTICA (data analysis software system), version 9.0 (2009), www.statsoft.com.

Tibary A., Manar S. 2018. Cryo-preservation of sperm and embryos in small ruminants. Rev. Mar. Sci. Agron. Vét. 6, 195-210.

Turchanov S. 2007. Biologicheskaya tsennost ottayannoy spermyi [The biological value of thawed sperm]. Zhivotnovod. Rossii 8, 45. [in Russian]

Verstegen J., Iguer-Ouada M., Onclin K. 2002. Computer assisted semen analyzers in andrology research and veterinary practice. Theriogenology 57(1), 149-179. 
